\title{
TAPADÓ HÓ KIALAKULÁSAKOR JELLEMZŐ VERTIKÁLIS RÉTEGZŐDÉS VIZSGÁLATA 36 ÉVNYI RÁDIÓSZONDÁS FELSZÁLLÁS MÉRÉSEI ALAPJÁN
}

\author{
Somfalvi-Tóth Katalin ${ }^{(1)}$ (D), Simon André( ${ }^{(2)}$, Mészáros Róbert ${ }^{(3)}$ \\ ${ }^{(1)}$ Kaposvári Egyetem, Természeti Erőforrások Tanszék, 7400 Kaposvár, Guba S. u. 40. \\ ${ }^{(2)}$ Országos Meteorológiai Szolgálat, 1024, Budapest, Kitaibel Pál utca 1. \\ ${ }^{(3)}$ ELTE Meteorológiai Tanszék, 1117 Budapest, Pázmány Péter sétány 1/A \\ e-mail: somfalvi-toth.katalin@ke.hu,simon.a@met.hu,mrobi@nimbus.elte.hu
}

\section{Bevezetés}

Már az 1800-as évek végén (Ju et al., 1899) szembesültek azzal, hogy az elektromos áramellátásban alapvető szerepet játszó távvezeték-hálózatokat nagymértékben veszélyeztetik bizonyos időjárási körülmények, események. Ilyen például a villámcsapás, a viharos szél, illetve a téli jégfelhalmozódás. A jég és hó súlytöbblete, főleg ha szeles idővel társul, könnyen nagy területen okozhat vezetékszakadást. A lerakódás lehet zúzmara, ónos esőből származó jégbevonat, vagy tapadó hó. A zúzmara a hazai éghajlati körülmények miatt ritkán éri el a kritikus súlytöbbletet, amely a vezeték elszakadásához vezethet. Ezzel szemben az ónos eső és tapadó hó gyakrabban okoz károkat. Az ónos eső kialakulási körülményeivel számos publikáció foglalkozik, amelynek Magyarországra vonatkozó vizsgálatait Fövényi (2001) végezte el. A vezetékre rakódó ónos, jeges bevonat egyszerübben előrejelezhető, ezzel szemben a tapadó hó kialakulásának folyamata még nem ismert minden részletében, illetve előrejelzése is bonyolultabb az alkalmazott parametrizációk miatt (ISO124194, 2001). Az elörejelzések pontosítása miatt fontos megvizsgálni rádiószondás felszállások segítségével, hogy tapadó hó észlelésekor milyen a légkör vertikális állapota, a hőmérsékleti, nedvességi és szélviszonyok alakulása.

A tapadó hó kialakulásához kedvező időjárási helyzetek gyakoriak hazánkban, egy téli félévben akár 35 tapadó havas napot is megfigyelhetnek (Gulyás, 2012). A legtöbb esetben néhány órán át tartó, kis csapadékintenzitású havazás tapasztalható enyhén pozitív talajközeli hőmérséklet mellett (Dalle \& Admirat, 2011). Ekkor káresemény nem történik. Ezzel szemben a hevesebb, akár 5-10 órán át tartó, nagy csapadékintenzitással és erős széllel járó havazás jelenti a legnagyobb kockázatot a felsővezeték-hálózat számára (Wakahama et al., 1977, Dalle \& Admirat, 2011). Magyarországon a mediterrán ciklonok átvonulásához kapcsolhatók leggyakrabban ezek az események (Gulyás, 2012).

A nedves hópelyhek megjelenése összetett mikrofizikai folyamatok eredménye, amelyben jelentős szerepet játszik a légkör vertikális szerkezete, a meteorológiai, azon belül is a termodinamikai állapothatározók (léghőmérséklet, légnyomás, légnedvesség) alakulása. A nemzetközi szakirodalomban a tapadó hóval kapcsolatos vizsgálatok két részre bonthatók. Egyrészt megtalálhatók a meteorológiai állomásokon mért adatokon (hőmérséklet, szélirány és szélsebesség, látástávolság) alapuló (Makkonen, 1989; Makkonen \& Wichura, 2010; Nygaard et al, 2013), másrészt a korlátos tartományú, nem-hidrosztatikus időjárás elörejelző modellek outputjaiból számított statisztikai vizsgálatok és előrejelzések (Grünewald et al., 2012; Somfalvi-Tóth et al., 2015; Lacavalla et al., 2015). Ez utóbbiak már rendkívül részletes mikrofizikai sémát használnak a téli csapadékfajták tulajdonságainak, mint például a felhőben megjelenő részecskék típusának (graupel, felhővíz, hó, eső, túlhült víz, stb.), a folyékony felhővíztartalomnak, a szilárd és folyékony halmazállapotú csapadékelemek arányának, vagy a hópelyhek tömegkoncetrációjának parametrizálására (Hong et al., 2004; Thompson et al., 2004; Thompson et al., 2008; Morrison et al., 2015). Ezeket a paramétereket nem mérik 
közvetlenül a meteorológiai állomások, ezért inicializálásuk a modellekben nem méréseken alapul, így az eredmények verifikálása is akadályokba ütközik.

\section{Felhasznált adatok és módszertan}

A különböző klimatológiai vizsgálatok és numerikus modellekkel történő előrejelzések elvégzéséhez szinte kivétel nélkül a talajközeli légréteg (2 méteres hőmérséklet, relatív nedvesség, látástávolság, 10 méteres szélirány és szélsebesség) állapota alapján határozzák meg a tapadó hó megjelenését (Wakahama, 1979; Matsuo et al., 1981; Admirat et al., 1988; Finstad et al., 1988; Makkonen 1989; Sakamoto \& Miura, 1993; Rasmussen et al., 1999; ISO12494, 2001; Makkonen \& Wichura, 2010; Nygaard et al., 2013). A felsőbb légrétegek állapotára viszont csak egy-egy rövidebb bejegyzést találunk (Dalle \& Admirat, 2011). Ezt a hiányosságot pótolandó, átfogó vizsgálatot végeztünk 36 évnyi rádiószondás felszállás adataiból.

Magyarországon két állomáson, Budapest Pestszentlörincen és Szegeden végeznek magaslégköri rádiószondás méréseket. Az 1980-as években orosz mérőszondákat használtak, de az 1990-es évek elejétől áttértek a Vaisala típusú rádiószondák alkalmazására. Jelenleg a Vaisala RS92 - SGP típusú rádiószondával történnek a mérések Budapesten. 2015. január 1-én kezdődött a GRAW DFM-09 típusú szondák tesztelése az Országos Meteorológiai Szolgálatnál, melyeket 2016-tól már az operatív szolgálatba is bevontak. Budapesten és Szegeden a 0 UTCs mérést a Vaisala szondával, míg a 12 UTC-s mérést a GRAW szondával hajtották végre. 2017 elejétől Budapesten mindkét mérés Vaisala szondával, míg Szegeden mindkét mérés GRAW szondával történik. Szegeden az 1990-es évek elejétől 2014. december 31-ig naponta egyszer végeztek mérést, majd 2015. január 1-től visszatértek a napi 2 mérésre (0 és 12 UTC). Budapest Pestszentlörincen 1980-1990 között napi 3 felszállás történt (0, 12 és 18 UTC), majd 1991-től napjainkig napi 2 mérést (0 és 12 UTC) végeznek.

Vizsgálatunkhoz az 1980-2016 közötti 36 éves időszakból származó rádiószondás méréseket használtuk fel, ezen belül is az 1000, 925, 900, 850, 800 és $700 \mathrm{hPa}$ fóizobárszintek adataival végeztük el vizsgálatainkat. Ennél magasabban elhelyezkedő nyomási szintek már nem relevánsak a tapadó hó kialakulásának szempontjából. Az adatbázisból egy megadott feltételrendszer szerint szürtük ki a tapadó hó előfordulásának időpontjait. Ezek a feltételek a következők:

1. A rádiószonda felbocsátásának időpontja előtti és utáni 2-2 órában, azaz 4 órás időszak alatt minimum egy észlelés során havazást regisztrálnak, miközben a léghőmérséklet a talaj közelében $[-0,5,+2]^{\circ} \mathrm{C}$ közötti intervallumba esik. Ennek a két feltételnek egyszerre kell teljesülnie.

2. Másodlagos szürést is végezni kellett, hiszen a légkörben zajló gyors változások miatt nem biztos, hogy a felszállás idejében is fennálltak a tapadó hó kialakulásának kedvező feltételek. Ha a felszállás idején az adatok alapján

a. túl hideg a légkör (minden vizsgált nyomási szinten negatív a hőmérséklet), vagy

b. túl meleg a légkör (minimum egy nyomási szinten $2{ }^{\circ} \mathrm{C}$ feletti a hömérséklet), akkor feltételezhetően hideg-, vagy melegadvekció miatt ezek a felszállások már nem reprezentálják a havazás idején jellemző vertikális hőmérsékleti, nedvességi és szélkarakterisztikákat, ezért ezeket az eseteket figyelmen kívül hagytuk.

Az 1980-2016 közötti időszak rádiószondás felszállásai közül összesen 1315 felelt meg a megadott feltételeknek. Budapest Pestszentlőrincre és Szegedre vonatkozó adatokat nem választottuk szét, illetve, ha ugyanazon napon mindkét állomásról végzett mérések megfeleltek a követelményeknek, akkor az esetszám növelése érdekében mindkét adatsort felhasználtuk a statisztikai elemzés során, hiszen az eredményekre nézve ez semmilyen torzítást nem jelent. 
Az adatok elemzéséhez és megjelenítéséhez az R statisztikai programot (2008) használtuk. Az ún. violin ábrák egy sürüségfüggvény és egy boxplot kombinációjaként állnak elő (Hintze \& Nelson, 1998).

\section{Eredmények: vertikális rétegződés tapadó havas események során}

A tapadó hó előfordulásakor jellemző vertikális rétegződés elemzésekor fontos tényező a 850/1000 relatív topográfia magassága. Hirsch (2008) szerint az 1300 gpm megközelítőleg jó határvonalat jelent a folyékony és szilárd halmazállapot elkülönítésére. Dalle \& Admirat (2011) felhívja a figyelmet, hogy a nedves hópelyhek megjelenésében kulcsfontosságú a $0{ }^{\circ} \mathrm{C}$-os izoterma magassága, illetve alatta egy 300-400 m vastag pozitív réteg megjelenése, ahol a hópelyhek részlegesen megolvadnak. A szakirodalomban a tapadó havas esetekben fennálló vertikális rétegződés jellemzésére nem találtunk további leírást vagy vizsgálatokat. A kapott eredmények azonban elengedhetetlenek az elörejelzések pontosítása érdekében.

Hirsch (2008) szerint havazás során az átlagos relatív topográfia érték 1280 gpm, a maximum 1325 gpm, míg a minimum kb. $1250 \mathrm{gpm}$. Tapadó havas helyzetekre is megvizsgáltuk a 850/1000 relatív topográfia alakulását, amelynek eredményeit az 1. ábrán tüntettük fel. Az ábra bal oldalán hisztogram, míg a jobb oldalán boxplot látható. Az eredmények szerint az átlagos relatív topográfia 1300 gpm, maximum 1320 gpm, míg a kiugró extrémumok figyelmen kívül hagyásával a minimum kb. $1265 \mathrm{gpm}$. Mivel a relatív topográfia a két nyomási szint közötti átlagos hőmérsékletet jellemzi, a magasabb értékek melegebb légréteg jelenlétére utalnak. Ugyanakkor a szükebb értéktartomány azt a feltételezést is megerősíti, hogy a jelenség érzékeny a hömérsékleti viszonyok alakulására.

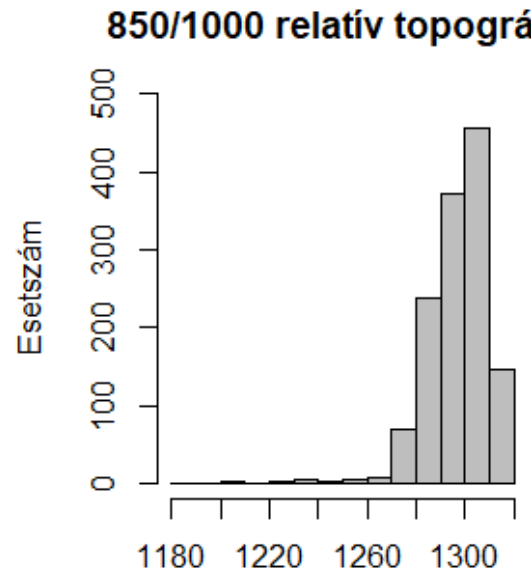

gpm

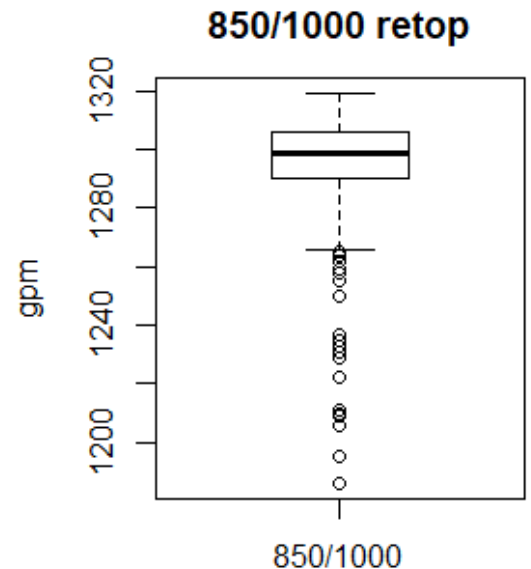

$\mathrm{hPa}$

1.ábra: Tapadó hó megjelenéséhez kapcsolódó 850/1000 relatív topográfia 36 évnyi budapesti és szegedi rádiószondás felszállások mérései alapján.

Tapadó hó kialakulásakor az egyik kulcsfontosságú tényező a hőmérséklet vertikális rétegződése. Az 1. táblázatban látható a pozitív és negatív rétegek elhelyezkedése egymáshoz képest, valamint az előfordulások száma. Az eredményekből kitünik, hogy a pozitív réteg elhelyezkedése 95,09\% relatív gyakorisággal közvetlenül a talaj felett helyezkedik el, míg a magasabb légréteg hőmérséklete negatív. A pozitív hőmérsékletủ réteg két negatív hőmérsékletü réteg közé ékelődése (4., 5., 6., 9. eset) az esetek elenyésző hányadában jellemző csak $(4,91 \%)$ 
1. táblázat: A pozitív hőmérsékletü réteg elhelyezkedése (9 típus), és a hozzájuk tartozó esetszám a budapesti és szegedi rádiószondás felszállások mérései alapján.

$\begin{array}{llllll}\text { Típus } & \mathbf{1 0 0 0} \mathbf{h P a} & 925 \mathbf{h P a} & \mathbf{9 0 0} \mathbf{h P a} & \mathbf{8 5 0} \mathbf{h P a} & \text { Esetszám } \\ \text { 1. } & + & - & - & - & 556 \\ \text { 2. } & + & + & - & - & 44 \\ \text { 3. } & + & + & + & - & 45 \\ \text { 4. } & - & + & - & - & 17 \\ \text { 5. } & - & + & + & - & 15 \\ \text { 6. } & - & - & + & - & 11 \\ \text { 7. } & & + & - & - & 244 \\ \text { 8. } & & + & + & - & 233 \\ \text { 9. } & & - & + & - & 16\end{array}$

A tapadás hatékonyságát a hópelyhek folyékony víztartalma határozza meg. Sakakibara et al. (2007) mérései szerint a hópehely $12-15 \%$-os folyékony víztartalom mellett tapad legerősebben a tereptárgyakhoz. Admirat \& Dalle (2011) szerint ehhez 300-400 méter vastag pozitív réteg szükséges. Budapesti és szegedi vizsgálataink szerint valóban leggyakoribb a 400 méteres rétegvastagság, míg egy másodlagos maximum alakul ki 800 méteres vastagságnál (2. ábra). Ilyen, vagy ennél vastagabb pozitív réteg jelenlétében a hópelyhek víztartalma valószínüleg már meghaladja az optimális víztartalmat, ezért tereptárgyakhoz ütközve lefolynak azok felületéről. Esetünkben ónos eső kialakulása kizárt, mivel szinoptikus észleléseket használtunk fel az esetek szürésére, aminek egyik alapfeltétele a havazás megléte volt.

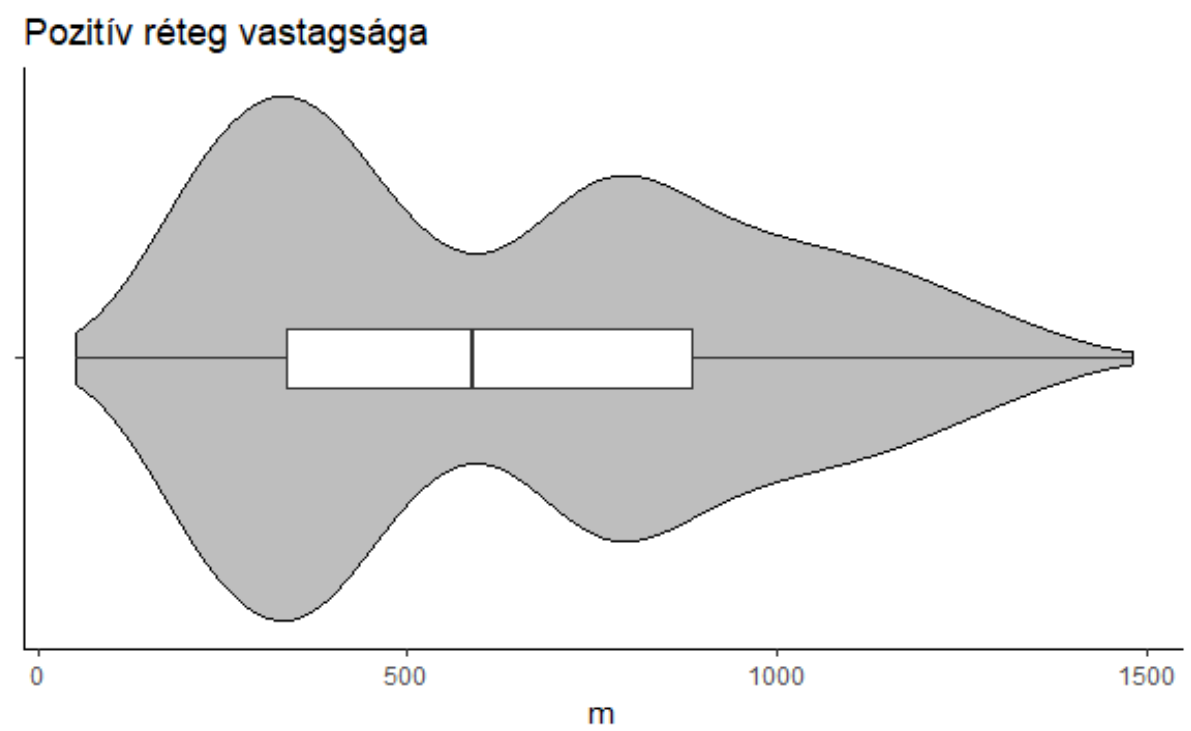

2. ábra: Violin ábra a pozitív réteg vastagságának elemzéséhez a budapesti és szegedi rádiószondás felszállások alapján. 
A hőmérsékleti gradiens értékéről a szakirodalomban egyáltalán nem találunk olyan vizsgálatokat, amelyek számszerüsítik annak alakulását tapadó havas események során. A 3. ábrán látható, hogy a hömérsékleti gradiens az alsó, 925-1000 hPa közötti rétegben nagyon szük tartományban mozog, $-0,3$ és $-0,4{ }^{\circ} \mathrm{C} / 100 \mathrm{~m}$ közötti értékeket vesz fel. A felette húzódó rétegek hőmérsékleti gradiensének átlaga a feltüntetett boxplot diagramok alapján néhány kiugró értéktől eltekintve $-0,6^{\circ} \mathrm{C} / 100 \mathrm{~m}$ körül alakul.

Hömérsékleti gradiens

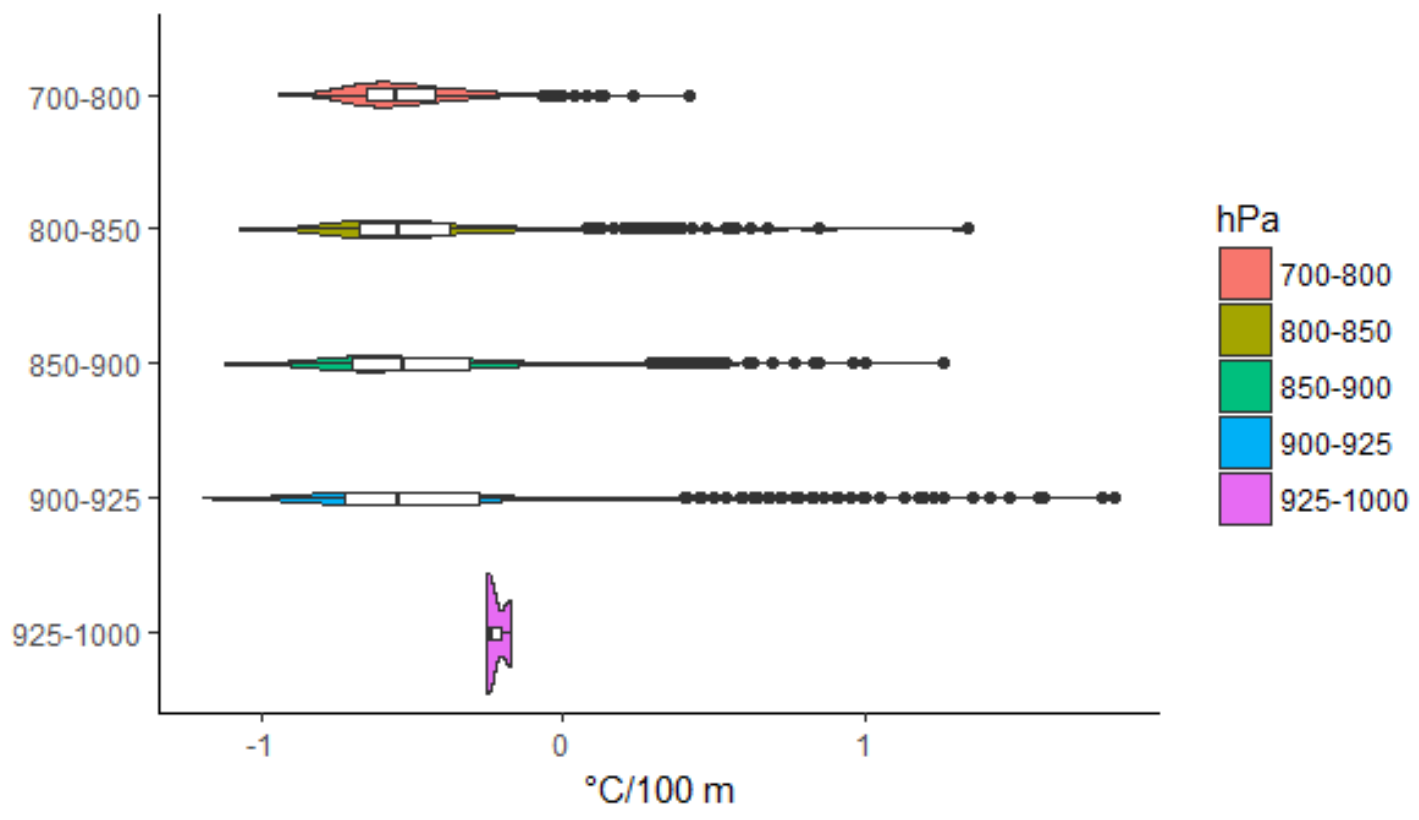

3. ábra: Hőmérsékleti gradiens különböző nyomási szintek között tapadó hó megjelenésekor budapesti és szegedi rádiószondás mérések alapján.

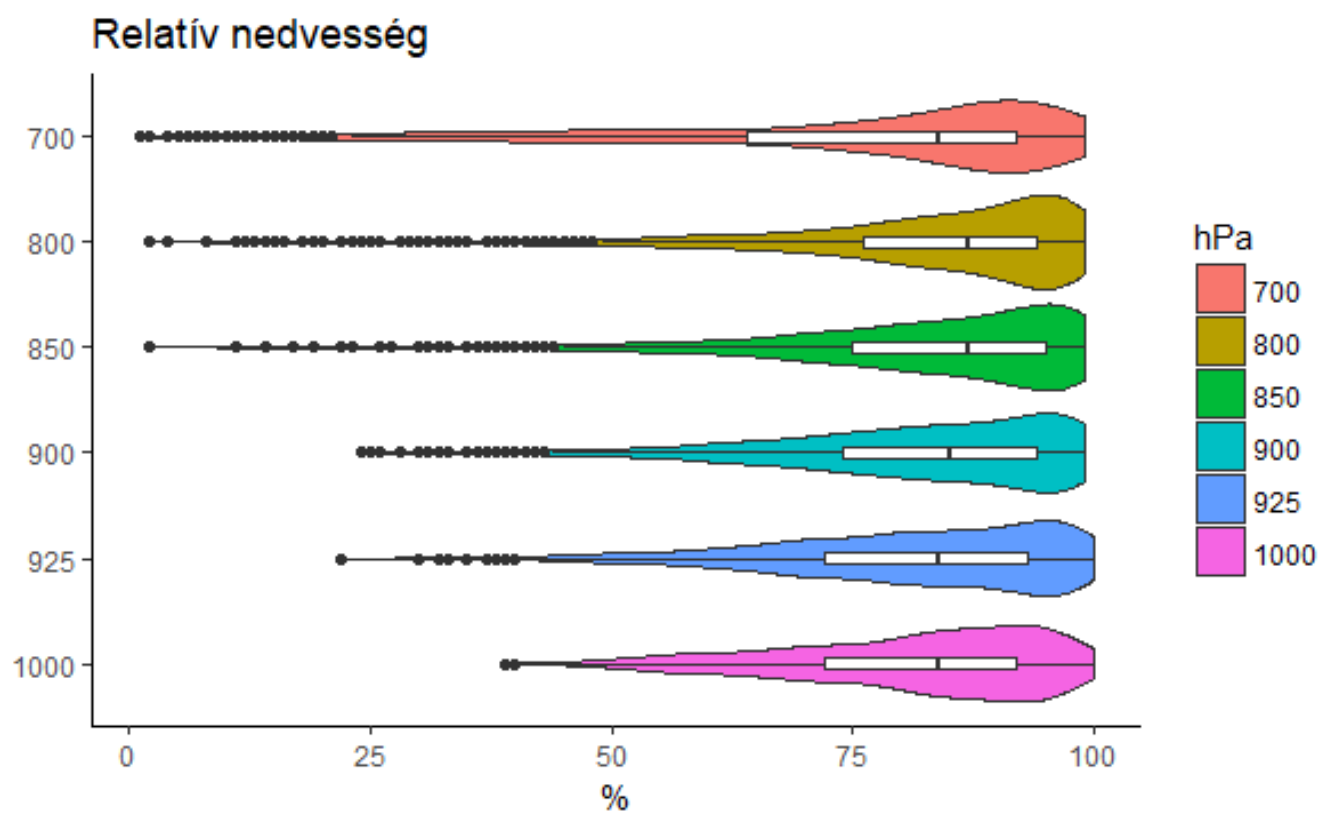

4. ábra: Relatív nedvesség vertikális eloszlása tapadó hó megjelenésekor 36 évi budapesti és szegedi rádiószondás felszállások alapján. 
A tapadó hó kialakulása szempontjából rendkívül fontos tényező a légkör nedvességtartalma. Sugimoto et al. (2016) 1970-2010 közötti in situ megfigyelések alapján arra a következtetésre jutott, hogy a tapadó hóban megjelenő folyékony víz mennyisége optimális a tapadáshoz, ha a léghőmérséklet $-0,5^{\circ} \mathrm{C}$ és $+1{ }^{\circ} \mathrm{C}$ között, míg a relatív nedvesség $93 \%$ és 100\% között alakul a talaj közelében. Az 1000 hPa-os mérések alapján a leggyakrabban 90\% és 95\% között alakul a relatív nedvesség (sürüségfüggvény alapján), míg a medián $85 \%$ körüli érték. A 925, 900, 850 és 800 hPa magasságban a relatív nedvesség értéke jobban megközelíti a 100\%-ot a sürüségfüggvények alapján (95\%, vagy felette) (4. ábra). A megfigyeléseinket tehát alátámasztják az eredmények, miszerint kedvezőbbek a tapadó hó kialakulásának feltételei, ha a talaj közelében szárazabb a levegő, aminek termodinamikai magyarázata van.

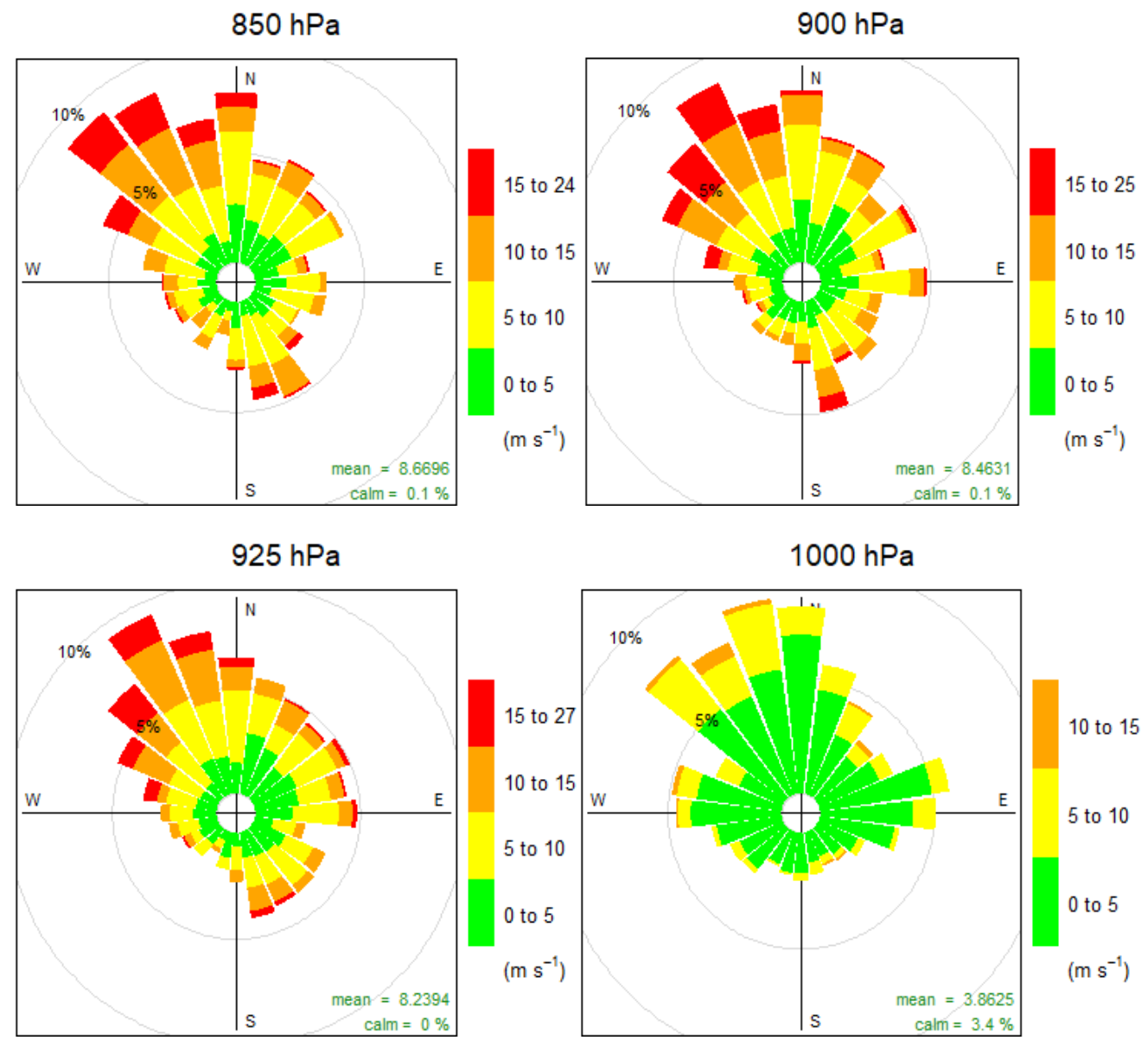

5. ábra: Szélirány és szélsebesség vizsgálata különböző nyomási szinteken 36 évi budapesti és szegedi rádiószondás mérések adatai alapján.

A talajközeli szélviszonyok is rendkívül fontos szerepet játszanak a felsővezetékekre veszélyes hófelhalmozódás kialakulása szempontjából. Az 5. ábrán láthatjuk az 1000, 925, 900, $850 \mathrm{hPa}$ nyomási szintekre jellemző szélrózsákat tapadó havas esetekben. Minden vizsgált nyomási szinten az északnyugati szélirány a leggyakoribb, míg a délnyugati szélirány a legkevésbé jellemző ezekben a helyzetekben. A legfontosabbak mégis a talajközeli légállapot, azaz az 1000 hPa-os szint szélviszonyai. A szél sebessége befolyásolja a hópelyhek fluxusát, ezáltal a hógyürü növekedésének ütemét, valamint a vezetéken felhalmozódó hógyürü sürüségét. Sakakibara et al. (2007) szerint $5 \mathrm{~m} / \mathrm{s}$ feletti szélsebesség mellett már kellően nagy a szél nyomóereje ahhoz, hogy a vezeték tengely körüli forgása meginduljon. Szélcsatorna kísérletek bizonyították, hogy $20 \mathrm{~m} / \mathrm{s}-i g$ megindulhat a felhalmozódás, ha stacionárius az áramlás (Wakahama et al., 1977; ISO12424, 2001). A szélsebesség növekedésének azonban 
összetettebb a hatása, ugyanis minél nagyobb a szélsebesség, annál kisebb a tapadás hatékonysága, amelyet a tapadási együttható (ß) fejez ki a számítások során. A tapadási együttható értéke fordítottan arányos a szélsebesség négyzetgyökével, illetve ha a szélsebesség $1 \mathrm{~m} / \mathrm{s}$ alatti, akkor a tapadási együttható értéke 1 (Nygaard et al., 2013). Mivel ezeket a paramétereket (hópelyhek vezetékre merőleges fluxusa, hógyürü sürüsége, tapadási együttható értéke) nagyon nehéz mérni, ezért csak közelíteni, becsülni tudjuk értéküket. Szélsebesség szempontjából pedig az $1000 \mathrm{hPa}$-os szint a releváns. Ezekben az időjárási helyzetekben nem jellemző hazánkban az erős szél, a leggyakrabban az $5 \mathrm{~m} / \mathrm{s}$-ot sem haladja meg a szélsebesség (esetek 75\%-a). Ugyanakkor a veszélyes mértékü hófelhalmozódásnak kedvezőbb, ha ennél erősebb a légmozgás (Sakakibara et al., 2007), ami magyarországi viszonyok között az esetek elenyészö hányadában (kb. 25\%, amelyböl a $10 \mathrm{~m} / \mathrm{s}-\mathrm{os}$ meghaladó szélsebesség aránya kb. 5\%) áll fenn.

\section{Összefoglalás}

A tapadó hó kialakulását alapvetően befolyásolja a légkör vertikális állapota. A szakirodalomban csak néhány utalást találtunk a hömérsékleti, nedvességi és szélviszonyokra, ezért 36 év rádiószondás méréseit használtuk fel annak bizonyítására, hogy valóban általános érvényüek ezek a feltételezések, illetve olyan tényezőket is vizsgáltunk, amikről eddig nem állt rendelkezésre információ (relatív topográfia, pozitív réteg elhelyezkedése, hőmérsékleti gradiens, jellemző talajközeli szélviszonyok). Az eredmények tükrében az alábbi következtetések vonhatók le:

1. A relatív topográfia értékek Hirsch (2008) havazással kapcsolatos eredményeinek egy szükebb tartományát fedik le (1250-1325 gpm helyett 1265-1320 gpm, ahol a medián 1280 gpm helyett 1300 gpm).

2. A pozitív réteg elhelyezkedése az esetek 95,09\%-ában közvetlenül a talaj felett helyezkedik el, amely leggyakrabban 400 méter vastagságú.

3. Vizsgálataink szerint az $1000-925 \mathrm{hPa}$ nyomási szint hőmérsékleti gradiense $-0,3{ }^{\circ} \mathrm{C} / 100 \mathrm{~m}$ és $-0,4^{\circ} \mathrm{C} / 100 \mathrm{~m}$ értékek között mozog.

4. Az $1000 \mathrm{hPa}$-os szint relatív nedvesség értékei alacsonyabbak, azaz a talajközeli légréteg szárazabb, mint a felette húzódó rétegek (relatív nedvesség mediánja 85\%, míg a sủrüségfüggvény alapján a leggyakoribb értékek $90 \%$ és $95 \%$ között vannak).

5. Tapadó hó kialakulásakor a vizsgált állomásokon a leggyakoribb szélirány minden szinten az északnyugati, míg legkisebb az előfordulási gyakorisága a délnyugati iránynak. A tapadó hó felhalmozódás szempontjából a legrelevánsabb az 1000 hPa-os nyomási szint szélsebessége. Az esetek döntő többségében (kb. 75\%) $5 \mathrm{~m} / \mathrm{s}$ alatt marad a légmozgás. 20\%-ban 5-10 m/s közötti, míg az esetek elenyésző (kevesebb, mint 5\%) hányadában haladja meg a $10 \mathrm{~m} / \mathrm{s}$-ot a szélsebesség.

\section{Hivatkozások}

Admirat, P., Sakamoto, Y., DeGoncourt, B., 1988: Calibration of a snow accumulation model based on actual cases in Japan and France. Proc. 1988 IWAIS, 129-133.

Dalle, B., Admirat, P., 2011: Wet snow accretion on overhead lines with French report of experience. Cold Reg. Sci. Technol., 65(1): 43-51. https://doi.org/10.1016/j.coldregions.2010.04.015

Finstad, K. Fikke, J., Ervik, M., 1988: A comprehensive deterministic model for transmission line icing applied to laboratory and field observations. Proc. 1988 IWAIS, 229-231. 
Fövényi, A., 2001: Probability forecast of state of winter precipitation uding NWP model data. Proc. of the Fifth European Conference on Applications of Meteorology, ECAM 2001. szeptember 24-28., Budapest, Magyarország.

Grünewald, T., Dierer, S., Cattin, R., Steiner, P., Steinkogler, W., Fundel, F., Lehning, M., 2012: Mapping frequencies of icing on structures in Switzerland. Journal of Wind Engineering and Industrial Aerodynamics, 107-108: 76-82. https://doi.org/10.1016/j.jweia.2012.03.022

Gulyás, K., Somfalvi-Tóth, K., Kolláth, K., 2012: A tapadó hó statisztikus-klimatológiai viszonyai hazánkban. Légkör, 57: 49-54.

Hintze, J.L., Nelson, R.D., 1998: Violin Plots: A Box Plot-Density Trace Synergism. The American Statistician, 52(2): 181-4. https://doi.org/10.1080/00031305.1998.10480559

Hirsch, T., 2008: Téli magyarországi nagy csapadékos helyzetek vizsgálata és elörejelzése. PhD értekezés, ELTE Földtudományi Doktori Iskola, 2008.

Hong, S., Dudhia, J.,Chen, S., 2004: A Revised Approach to Ice Microphysical Processes for the Bulk Parameterization of Clouds and Precipitation. Mon. Weather Rev., 132: 103-120. https://doi.org/10.1175/1520-0493(2004)132<0103:ARATIM>2.0.CO;2

ISO, 2001: Atmospheric icing of structures. International Standardization Organisation (ISO) International Standard 12494, Geneva, Switzerland.

$J u, Y$., Li H., Xue, Q., 1899: Failure Analysis of Transmission Tower under the Effect of IceCovered Power Transmission Line. Information Science and Engineering, International Conference on (ICISE), Nanjing, Jiangsu China, 4301-4304. https://doi.org/10.1109/ICISE.2009.586

Lacavalla, M., Marcacci, P., Freddo, A., 2015: Wet-snow activity research in Italy. Proc. 16th Int. Workshop on Atmospheric Icing of Structures (IWAIS), Uppsala, Finnland, 17-24.

Makkonen, L, 1989: Estimation of wet-snow accretion on structures. Cold Reg. Sci. Technol., 17: 83-88. https://doi.org/10.1016/S0165-232X(89)80018-7

Makkonen, L. Wichura, B., 2010: Simulating wet-snow loads on power line cables by a simple model. Cold Reg. Sci. Technol., 61: 73-81. https://doi.org/10.1016/j.coldregions.2010.01.008

Matsuo, T., Sashio, Y., Sato, Y., 1981: Relationship between Types of Precipitation on the Ground and Surface Meteorological Elements. J. Met. Soc. of Japan, 59(4): 462-476. https://doi.org/10.2151/jmsj1965.59.4 462

Morrison, H., Milbrandt, J.A., Bryan, G.H., Ikeda, K., Tessendorf, S.A., Thompson, G., 2015: Parameterization of Cloud Microphysics Based on the Prediction of Bulk Ice Particle Properties. Part II: Case Study Comparisons with Observations and Other Schemes. $J$. Atmos. Sci., 72: 312-339. https://doi.org/10.1175/JAS-D-14-0066.1

Nygaard, B.E.K., Ágústsson, H.,Somfalvi-Tóth, K., 2013: Modeling Wet Snow Accretion on Power Lines: Improvements to Previous Methods Using 50 Years of Observations. J. Appl. Meteor. Climatol., 52: 2189-2203. https://doi.org/10.1175/JAMC-D-12-0332.1

Rasmussen, R.M., Vivekanandan, J., Cole, J., Myers, B., Masters, C., 1999: The Estimation of Snowfall Rate Using Visibility. J. Appl. Meteor., 38: 1542-1563. https://doi.org/10.1175/1520-0450(1999)038<1542:TEOSRU $>2.0 . \mathrm{CO} ; 2$

$R$ Development Core Team, 2008: R: A language and environment for statistical computing. $\mathrm{R}$ Foundation for Statistical Computing, Vienna, Austria. ISBN 3-900051-07-0, URL http://www.R-project.org.

Sakakibara, D., Nakamura, Y., Kawashima, K., Miura, S., 2007: Experimental result for snow accretion characteristics of communications cable. Proc. Int. Wire and Cable Symp. (IWCS), Lake Buena Vista, FL, 581-586. 
Sakamoto, Y., Miura, A., 1993: Comparative study of wet snow models for estimating snow load on power lines based on general meteorological parameters. Proc. 1993 IWAIS, 133138.

Somfalvi-Tóth, K., Simon, A., Kolláth, K., Dezsö, Zs., 2015: Forecasting of wet- and blowing snow in Hungary. Időjárás, 119: 277-306.

Sugimoto, S., Ishikawa, T., Matsumiya, H., Nishihara, T., 2016: Practical Methods for Estimating Snow Accretion of Overhead Power Lines and Its Impact on Tower Members. Cigre-IEC Colloquium, 2016. május 9-11. Montreal, Kanada.

Thompson, G., Rasmussen, R.M., Manning, K., 2004: Explicit Forecasts of Winter Precipitation Using an Improved Bulk Microphysics Scheme. Part I: Description and Sensitivity Analysis. Mon. Weather Rev., 132: 519-542. https://doi.org/10.1175/15200493(2004)132<0519:EFOWPU>2.0.CO;2

Thompson, G., Field, P.R., Rasmussen, R.M., Hall, W.D., 2008: Explicit Forecasts of Winter Precipitation Using an Improved Bulk Microphysics Scheme. Part II: Implementation of a New Snow Parameterization. Mon. Weather Rev., 136: 5095-5115. https://doi.org/10.1175/2008MWR2387.1

Wakahama, G., Kuroiwa, D., Goto, K., 1977: Snow Accretion on Electric Wires and its Prevention. Journal of Glaciology, 19(81): 479-487. https://doi.org/10.3189/S0022143000215682.

Wakahama, G., 1979: Experimental studies of snow accretion on electric lines developed in a strong wind. J. Nat. Disast. Sci., 1: 21-33.

\section{ORCID}

Somfalvi Tóth K. (iD https://orcid.org/0000-0001-7404-6704

Mészáros R. (D) https://orcid.org/0000-0002-0550-9266 